\title{
Working
}

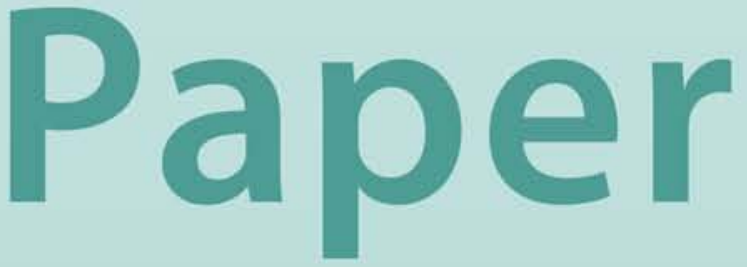


Slowdown of Credit Flows in Jordan in the Wake of the Global Financial Crisis: Supply or Demand Driven?

Tigran Poghosyan 


\title{
IMF Working Paper
}

Middle East and Central Asia Department

\section{Slowdown of Credit Flows in Jordan in the Wake of the Global Financial Crisis: Supply or Demand Driven?}

\author{
Prepared by Tigran Poghosyan ${ }^{1}$
}

Authorized for distribution by Paul Cashin

November 2010

\begin{abstract}
This Working Paper should not be reported as representing the views of the IMF. The views expressed in this Working Paper are those of the author(s) and do not necessarily represent those of the IMF or IMF policy. Working Papers describe research in progress by the author(s) and are published to elicit comments and to further debate.
\end{abstract}

This paper estimates a disequilibrium model of credit supply and demand to evaluate the relative role of these factors in the slowdown of credit flows in the Jordanian economy in the wake of the global financial crisis. The empirical analysis suggests that the credit stagnation is mainly driven by the restricted credit supply amid tighter monetary policy conditions in Jordan relative to the United States, as evidenced by the widened interest differential between the Central Bank of Jordan (CBJ) re-discount and the U.S. Federal Reserve funds rates. Although it appears that demand side factors related to the slowdown of economic activity have also had an impact, their role has been relatively modest. The estimation results imply that economic policies targeted towards stimulating supply of credit are likely to be a more effective tool for expanding credit flows relative to demand-stimulating policies.

JEL Classification Numbers: $\quad$ E44, G21, G28

Keywords: credit crunch, financial crisis, Jordan

Author’s E-Mail Address: $\quad$ TPoghosyan@imf.org.

\footnotetext{
${ }^{1}$ I would like to thank participants at the joint Central Bank of Jordan-IMF Research Workshop (July 2010), as well as Adel Al-Sharkas, Adolfo Barajas, Paul Cashin, and Anna Ter-Martirosyan for their helpful suggestions and comments. The usual disclaimer applies.
} 


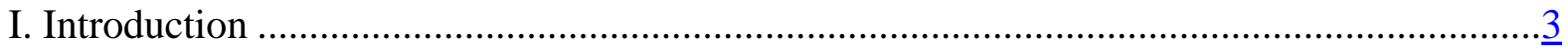

II. Disequilibrium Models: A Brief Survey of the Literature ....................................................

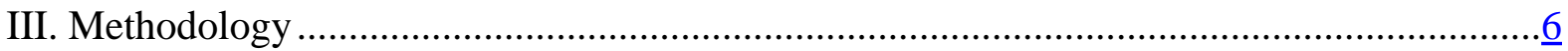

A. The Credit Supply Equation...................................................................................

B. The Credit Demand Equation...............................................................................

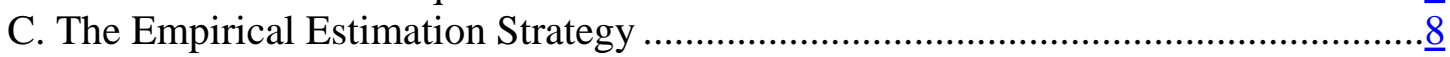

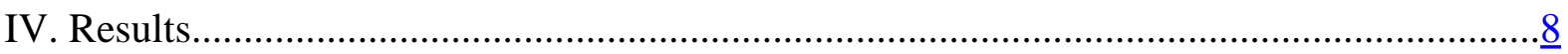

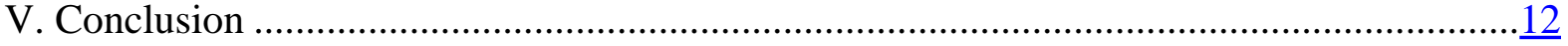

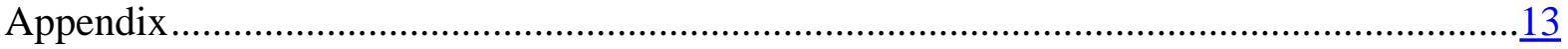

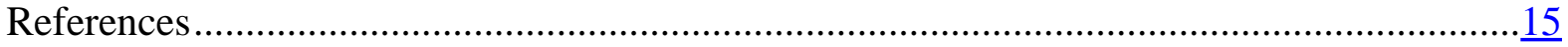

Tables

Table 1: Maximum Likelihood Estimations of Disequilibrium Model ...................................... $\underline{9}$

Figures

Figure 1. Jordan: Interest Rates, Credit to the Private Sector and Excess Reserves.................... 4

Figure 2. Jordan: Dynamics of Predicted Credit Demand and Supply (JD millions)................11

Figure 3. Jordan: Deviation of Demand and Supply from Observed Credit Volume................11 


\section{INTRODUCTION}

The global financial crisis has resulted in a worldwide slowdown of credit flows, which triggered a discussion about the factors driving sluggish lending activity. Unlike previous prominent crises (e.g. in East Asia and Latin America in the 1990s), the current slowdown in lending is taking place in the absence of rising cost of credit and amid record-low policy rates and monetary stimulus. Although the decline in credit flows can be rationalized in view of the overall decline in economic activity, some critics have argued that the slowdown of lending (despite generally low interest rates) can be attributed to credit rationing by banks. According to this "credit crunch" hypothesis, in the presence of asymmetric information interest rates do not equilibrate supply of and demand for credit, and rational profitmaximizing lenders deliberately constrain the outflow of liquidity in an attempt to avoid the accumulation of risky assets.

Understanding whether sluggish credit activity is related to constrained supply or weak demand for credit is important from a policy perspective. If the reduction of credit flows is mainly a response to tightened credit standards by banks, then targeted monetary easing coupled with regulatory measures aimed at relaxing prudential norms may be needed to remove the obstacles for credit growth. ${ }^{2}$ Alternatively, if the reduction of credit flows is mostly driven by the decline in credit demand amid slower business activity, then economic policies aimed at expanding aggregate demand might be more effective in stimulating credit growth.

In an attempt to identify the relative role of credit supply and demand factors, we estimate a disequilibrium credit market model pioneered by Laffont and Garcia (1977) using Jordanian data. Similar to the other countries in the Middle East, Jordan has experienced a slowdown in credit activity following the global financial crisis, which has corresponded with a widening gap between the Central Bank of Jordan (CBJ) and the U.S. Federal Reserve's (Fed) funds policy rates, an increase in the real lending rate, and mounting excess reserves of banks (see Figure 1). Our estimations suggest that even thought there is some evidence of decline in credit demand from the private sector, the observed slowdown in bank lending has been mainly in reaction to tightened supply of credit following the global financial crisis. In a nutshell, these results support the "credit crunch" hypothesis in Jordan and suggest that policies aimed at expanding supply of credit are key for accelerating lending activity in the wake of the global financial crisis.

\footnotetext{
${ }^{2}$ Among others, this view has been advocated by experts favoring countercyclical regulation of banks, according to which capital requirements imposed on banks should be relaxed in times of economic slowdown and strengthened in times of economic boom.
} 
Figure 1. Jordan: Interest Rates, Credit to the Private Sector and Excess Reserves

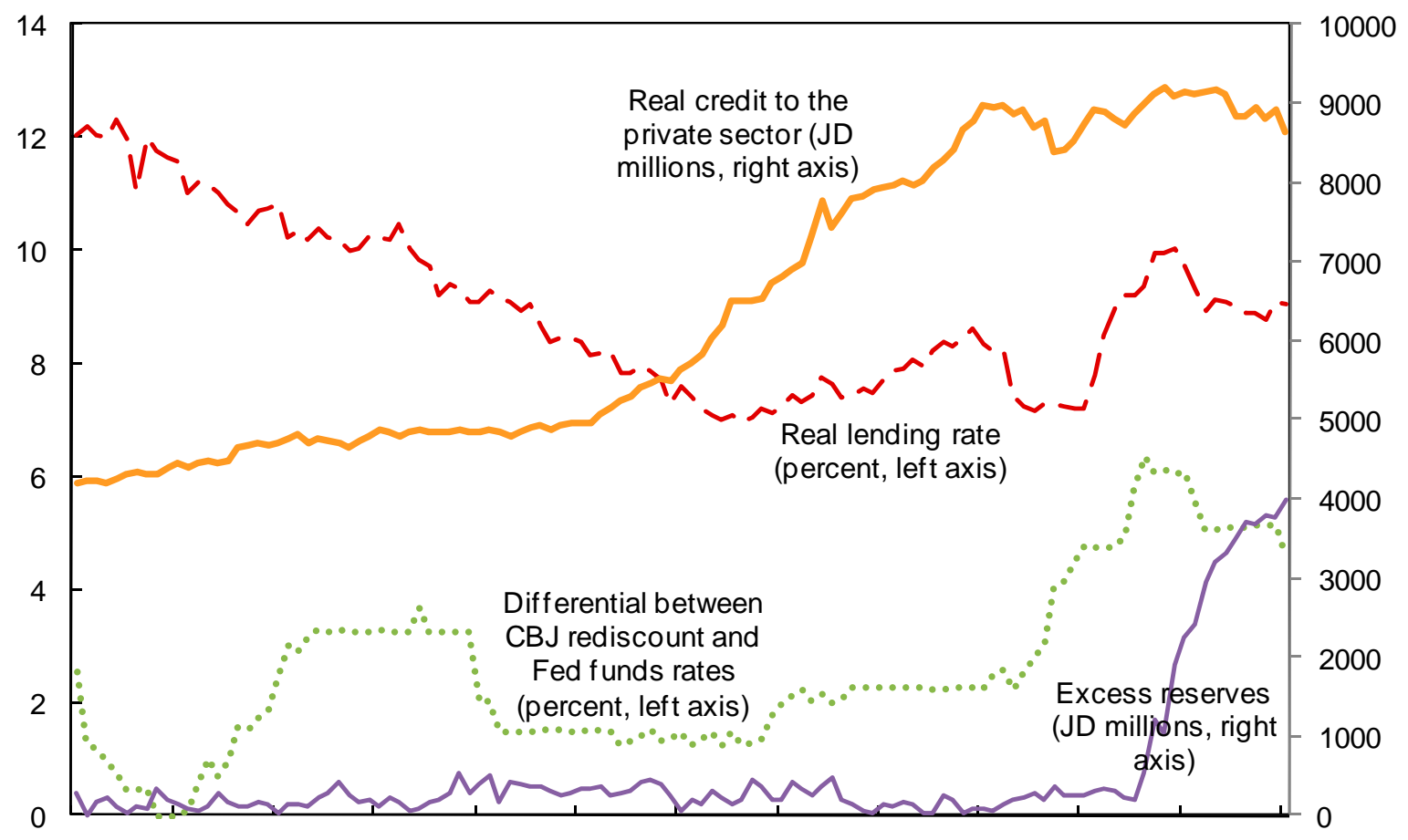

Jan-00 Nov-00 Sep-01 Jul-02 May-03 Mar-04 Jan-05 Nov-05 Sep-06 Jul-07 May-08 Mar-09 Jan-10

The remainder of the paper is structured as follows. Section II provides a brief review of the disequilibrium model and its applications. Section III describes the methodology and discusses the empirical estimation strategy. Section IV presents estimation results. The final section concludes.

\section{Disequilibrium Models: A BRIEF SURVEy OF THE Literature}

In a seminal credit rationing paper, Stiglitz and Weiss (1981) show that loan markets can be frequently characterized by a disequilibrium status. In the presence of asymmetric information, loan rates are not presumed to adjust in each period to clear the market (i.e., there is loan rate stickiness) and banks can ration the volume of credit on the basis of nonprice terms of the credit contract. From an econometric point of view, the main challenge associated with estimating the market model in disequilibrium is that one has to obtain estimators for the parameters of loan supply and demand functions using only observed volume of transactions in the loan market.

Laffont and Garcia (1977) offer a solution to this problem by employing the assumption of the "short side" principle in which the observed credit quantity is constrained to be the smallest of the unobserved demanded and supplied volumes. According to this framework, at a given point in time the credit market can exhibit temporary disequilibrium (excess supply or excess demand) owing to imperfect flexibility in the interest rate. Hence, the observed decline in real credit can be either due to falling supply of credit, or falling demand for credit, or both. The identification problem is solved by using exclusion restrictions on the supply and demand functions (e.g., banks’ lending capacity affects supply of credit, but not demand 
for credit). Maddala and Nelson (1974) discuss the appropriate maximum likelihood method for this class of disequilibrium models, which has been used for empirical analysis of credit markets in different countries.

Pazarbasioglu (1997) estimates a disequilibrium model of credit demand and supply for Finland for the period 1981-95. Credit demand is modeled as a function of the cost of credit and state of the overall economic environment, while credit supply is linked to the return on credit and resources available to the banks. The author finds that the sharp decline of lending in the Finnish economy following the banking crisis of 1991-92 was not a reflection of a credit crunch but was mainly caused by a cyclical decline in credit demand. Ghosh and Ghosh (1999) build on the work of Pazarbasioglu and differentiate between two components of possible decline in credit supply: banks' lending capacity (ability to lend) and risk aversion (willingness to lend). Using data on Indonesia, Korea, and Thailand in the aftermath of the 1997-98 East Asian crisis they show that both credit supply and demand have shown signs of stagnation, but the decline in demand was more pronounced. Barajas and Steiner (2002) adopt the disequilibrium approach to investigate the causes of credit slowdown in three Latin American countries (Colombia, Mexico, and Peru). They augment the model by incorporating regulatory variables in the supply equation and conclude that while supply expansion was primarily driven by lending capacity, regulatory variables became key during the slowdown.

Kim (1999) applies the disequilibrium approach for analyzing the impact of the Asian crisis on Korea. In contrast to Ghosh and Ghosh, the author includes a dummy variable for the post-crisis period in the supply equation and reports a significant negative coefficient. Kim concludes that severe credit contraction in Korea in the aftermath of the crisis was mainly driven by a sharp decline in credit supply, supporting the credit crunch hypothesis. Using a slightly different approach, Agénor et al. (2000) also find indirect support for the credit crunch hypothesis in Thailand. They develop a model of optimal excess reserves held by banks and show that these were modest in Thailand. If the slowdown in credit was caused by a reduction in demand for loans, then there would have been involuntary accumulation of excess reserves by banks, which was proven not to be the case in Thailand.

The above discussion suggests that the evidence on credit crunch from previous crisis episodes is mixed. One important difference between the recent global financial crisis and the crises analyzed in previous work is the behavior of interest rates: while nominal interest rates have been on the rise during previous crises, they have not gone up during the recent financial crisis owing to an unprecedented fiscal and monetary stimulus exercised by governments around the world. This was also the case in Jordan, where nominal lending rates were flat during the crisis, while real lending rates peaked amid a decelerating rate of inflation. Comparison of disequilibrium estimations in Jordan with the results in previous studies would therefore provide an illustration on how interest rate behavior can affect credit markets in crisis. 


\section{Methodology}

We adopt the disequilibrium framework of Laffont and Garcia (1977) used by previous studies to analyze credit demand and supply in other countries. According to this framework, at a given point in time the credit market can exhibit temporary disequilibrium (excess supply or excess demand) owing to imperfect flexibility in interest rates. Hence, the observed decline in real credit can be either due to falling supply of credit, or falling demand for credit, or both. The identification problem is solved by using exclusion restrictions on the supply and demand functions (e.g., banks' lending capacity affects supply of credit, but not demand for credit). Below we present the demand and supply equations for the real credit to the private sector, followed by the description of the estimation strategy.

\section{A. The Credit Supply Equation}

Following the previous literature and taking into account the Jordan-specific economic environment, the following variables are used as determinants of credit supply:

Return on credit $\left(i^{l}\right)$. This variable, approximated by the real lending rate (nominal loan rate minus smoothed inflation ${ }^{3}$ ), indicates the rate of return raised by banks from credit provision. A higher real lending rate is expected to make lending more attractive to banks and expand their credit supply.

Differential between CBJ re-discount rate and the U.S. Federal Reserve's (Fed) funds rate (im). Given the peg of the Jordanian dinar against the U.S. dollar, monetary policy in Jordan is closely linked to monetary policy in the U.S. Hence, the interest differential between policy rates in Jordan and the U.S. indicates the relative stance of monetary policies in these two countries. A wider differential implies a relatively stricter monetary policy in Jordan, and is expected to have a negative impact on credit supply. Therefore, the coefficient of this variable is expected to be negative.

Future economic prospects $\left(I P^{e}\right)$. Banks are expected to expand credit supply when expecting brighter economic prospects for the economy. We proxy economic prospects smoothed industrial production index (taken with a lag).

Lending capacity ( $L C$ ). Given expected returns on lending, banks should take into account the amount of available resources in deciding the amount of their credit portfolio. We proxy the real lending capacity of banks by the difference between total deposits and required reserves in the CBJ overnight facility deflated by the CPI (in logs). A higher lending capacity is expected to expand potential credit supply by banks.

Economic uncertainty (UNC). We proxy economic uncertainty by a rolling standard deviation of the log difference between the monthly Amman stock exchange index and its

\footnotetext{
${ }^{3}$ Inflation is smoothed using MA $(4,1,4)$ representation using the following formula: $1 / 9 *\left(x_{t-4}+x_{t-3}+x_{t-2}+x_{t-1}+\right.$ $x_{t}+x_{t+1}+x_{t+2}+x_{t+3}+x_{t+4}$ ), where $x_{t}$ is monthly CPI inflation. This approach was applied also for smoothing the growth of the industrial production and stock market indices.
} 
smoothed value (taken with a lag). We expect a negative coefficient on this variable, since banks' willingness to lend is likely to diminish in times of economic uncertainty.

Using these determinants, the credit supply equation takes the following form:

$C_{t}^{S}=\alpha_{0}+\alpha_{1} i_{t}^{l}+\alpha_{2} i m_{t}+\alpha_{3} I P^{e}{ }_{t-1}+\alpha_{4} L C_{t}+\alpha_{5} U N C_{t-1}+\varepsilon^{S}{ }_{t}$

where $\varepsilon^{S}$ is the i.i.d. error term.

\section{B. The Credit Demand Equation}

Credit demand is modeled as a function of the following variables:

Cost of credit $\left(i^{l}\right)$. The demand for bank credit is expected to depend negatively on its cost as proxied by the real lending rate. Thus, unlike the supply equation, this coefficient is expected to be negative.

Future economic prospects $\left(I P^{e}\right)$. Developments in the macroeconomic and business environment influence the decision of firms to expand or contract their business, which is crucial for credit applications. Similar to the supply equation, we expect a positive coefficient for this variable.

Lagged growth of real Amman Stock Exchange index (ASE). The impact of stock market activity on demand for bank credit is a priori unclear. On the one hand, expansion in stock market activity may increase demand for credit due to improved economic prospects. On the other hand, a rising value of stocks might improve the ability of businesses to acquire external funding from the financial market and reduce their demand for bank credit. Which of these two effects dominates is an empirical question.

Iraq war effect ( $T$ and Tsq). The demand equation also features a linear trend and its square, beginning in 2004 (in logs). These variables enter to capture the impact of the Iraq War on credit flows in Jordan. Specifically, the inflow of Iraqi refugees to Jordan appears to have placed additional pressure on credit demand, as evidenced by a rapid acceleration of observed credit volumes since the beginning of the war (see Figure 1). The inclusion of the quadratic term ensures that the marginal effect of the trend is diminishing over time, as refugees are expected to return to Iraq after stabilization of its economic situation, or to move to other countries outside the region.

Using these determinants, the credit demand equation takes the following form:

$$
C_{t}^{D}=\beta_{0}+\beta_{1} i_{t}^{l}+\beta_{2} I P_{t-1}^{e}+\beta_{3} A S E_{t-1}+\beta_{4} T+\beta_{5} T s q+\varepsilon^{D}
$$

where $\varepsilon^{D}$ is the i.i.d. error term. 


\section{The Empirical Estimation Strategy}

The disequilibrium hypothesis suggests that actual observed credit at time period $t$, $C_{t}$, lies either on the supply curve (excess demand), or on the demand curve (excess supply), or on both (equilibrium). Algebraically, this assumption can be expressed as:

$C_{t}=\min \left(C_{t}^{S}, C_{t}^{D}\right)$

where $C^{S}$ and $C^{D}$ are credit supply and demand functions defined in equations (1) and (2), respectively. As shown in Maddala and Nelson (1974), in the absence of any information regarding the price adjustment process and assuming that the error terms $\varepsilon^{S}$ and $\varepsilon^{D}$ are normally distributed random variables, the above model can be solved using the maximum likelihood method. The log-likelihood function is defined as follows (see Appendix for the derivations):

$$
L L=\sum_{t=1}^{T} \log \left[f^{D}\left(C_{t}\right) F^{S}\left(C_{t}\right)+f^{S}\left(C_{t}\right) F^{D}\left(C_{t}\right)\right]
$$

where $f($.$) and F($.$) are probability density and cumulative density functions, respectively. We$ optimize the log-likelihood function (4) using the BHHH (Berndt, Hall, Hall, and Hausman, 1974) iterative procedure.

\section{Results}

Table 1 displays estimation results of the disequilibrium model of credit for Jordan, using data for the period December 1999 to January 2010. Most of the coefficients are significant and all have expected signs. Standard deviation errors in both supply and demand equations are significantly different from zero, providing support for the chosen model specification.

The estimations suggest that both supply and demand for credit in the Jordanian banking system are positively affected by expected economic prospects. Similarly, the real lending rate has a positive impact on credit supply, while its impact on credit demand is negative. However, the interest rate elasticity of credit demand is somewhat lower than the interest rate elasticity of credit supply, suggesting that the demand curve is steeper than the supply curve. This finding does not come as a surprise given the developing nature of the Jordanian economy, where the monetary policy transmission mechanism works largely through the monetary aggregates rather than the interest rate (see Poddar et al., 2006).

In addition to the lending rate, the supply of credit is also affected by the differential between the CBJ rediscount and the U.S. Federal Reserve's (Fed) funds rate, which proxies the tightness of CBJ monetary policy relative to the Fed's monetary policy. The negative sign of this coefficient suggests that a tighter monetary policy in Jordan relative to that of the U.S. reduces the supply of credit. Related to this, a higher CBJ policy rate increases bank returns on excess reserves, further discouraging lending to the real sector. 
Table 1: Maximum Likelihood Estimation of Disequilibrium Model

\begin{tabular}{lr}
\hline Credit supply & \\
\hline Real lending rate & $0.04^{\star \star}$ \\
& {$[3.01]$} \\
Differential between CBJ rediscount and Fed funds rates & $-0.03^{\star}$ \\
& {$[-2.17]$} \\
Industrial production index (lagged) & $2.94^{\star \star \star}$ \\
& {$[7.69]$} \\
Standard deviation of ASE index growth (lagged) & -0.02 \\
& {$[-1.37]$} \\
Lending capacity & $0.47^{\star}$ \\
Constant & {$[2.19]$} \\
& $-9.15^{\star \star \star}$ \\
Credit demand & {$[-7.32]$} \\
\hline Real lending rate & \\
Industrial production index (lagged) & $-0.02^{\star \star \star}$ \\
& {$[-7.19]$} \\
Lagged real ASE index growth (smoothed) & $0.51^{\star \star \star}$ \\
& {$[8.97]$} \\
Time trend (logs) & $-0.01^{\star \star \star}$ \\
Time trend^2 (logs) & {$[-3.53]$} \\
& $-0.09^{\star \star \star}$ \\
Constant & {$[-9.98]$} \\
& $0.05^{\star \star \star}$ \\
Number of obs. & {$[20.10]$} \\
Akaike information criterion & $6.42^{\star \star \star}$ \\
Sayes-Schwartz information criterion & {$[23.15]$} \\
\hline & 134 \\
& 306.0 \\
& -584.0 \\
& -544.0 \\
& $0.04^{\star \star \star}$ \\
& {$[6.39]$} \\
& $0.02^{\star \star \star}$ \\
& {$[12.86]$} \\
\hline
\end{tabular}

Notes: Dependent variable is real credit to the private sector (in logs).

Estimations are performed using the the $\mathrm{BHHH}$ iterative procedure. $t$-statistics are reported in brackets. *, **, and *** denote significance at 10, 5, and 1 percent levels, respectively. 
In addition to the price effects, we single out two possible motives governing the supply of bank credit: availability of lendable resources (ability to lend) and risk aversion (willingness to lend in uncertain times). The coefficient of lending capacity (proxied by the difference between total deposits and required reserves) is strongly significant and positive, suggesting that higher lending capacity expands banks' potential to lend. Similarly, economic uncertainty (proxied by a rolling standard deviation of the monthly Amman Stock Exchange index ratio relative to its smoothed value, in logs) has a negative impact on banks' willingness to lend. The magnitude of the latter coefficient is small (and statistically insignificant) relative to the former (0.47), suggesting that while banks slightly reduce credit supply in times of financial market volatility, the main factor driving credit supply is the availability of funds.

Finally, we find a negative association between stock market activity and demand for credit. This implies that sluggish stock market developments put additional pressure on the ability of firms to acquire external funding, generating additional demand for bank credit. Credit demand has also been affected by the war in Iraq, as shown by the significant coefficients of trend variables.

Figures 2-3 display estimates of demand for and supply of credit obtained from the disequilibrium model, and their deviations from observed volumes of lending. The plotted credit supply and demand series suggest that the recent slowdown in credit flows is mainly driven by sluggish credit supply, affected by the widening differential between the CBJ rediscount and Fed funds rates. The demand for credit has also been affected in the wake of the global financial crisis. Credit demand flattened in 2008 amid the slowdown in Jordanian economic activity, but has rebounded since the beginning of 2009 as declining stock prices have dried up alternative sources of external funding for businesses.

Starting in mid-2009, the ability of banks to potentially expand the supply of credit has risen due to a combination of the following factors: (i) reduction of the CBJ policy rate and its differential with the Fed funds rate; (ii) elimination of the issuance of CBJ certificates of deposit and consequent accumulation of excess reserves by commercial banks; and (iii) the potential increase in deposit inflows (including unrecorded financial flows from abroad). Nevertheless, the predicted supply of credit by the end of the sample (January 2010) is still about 7 percent lower than predicted demand, suggesting that credit supply still has a large potential for further expansion (see also International Monetary Fund, 2010). 
Figure 2. Jordan: Dynamics of Predicted Credit Demand and Supply (JD millions)

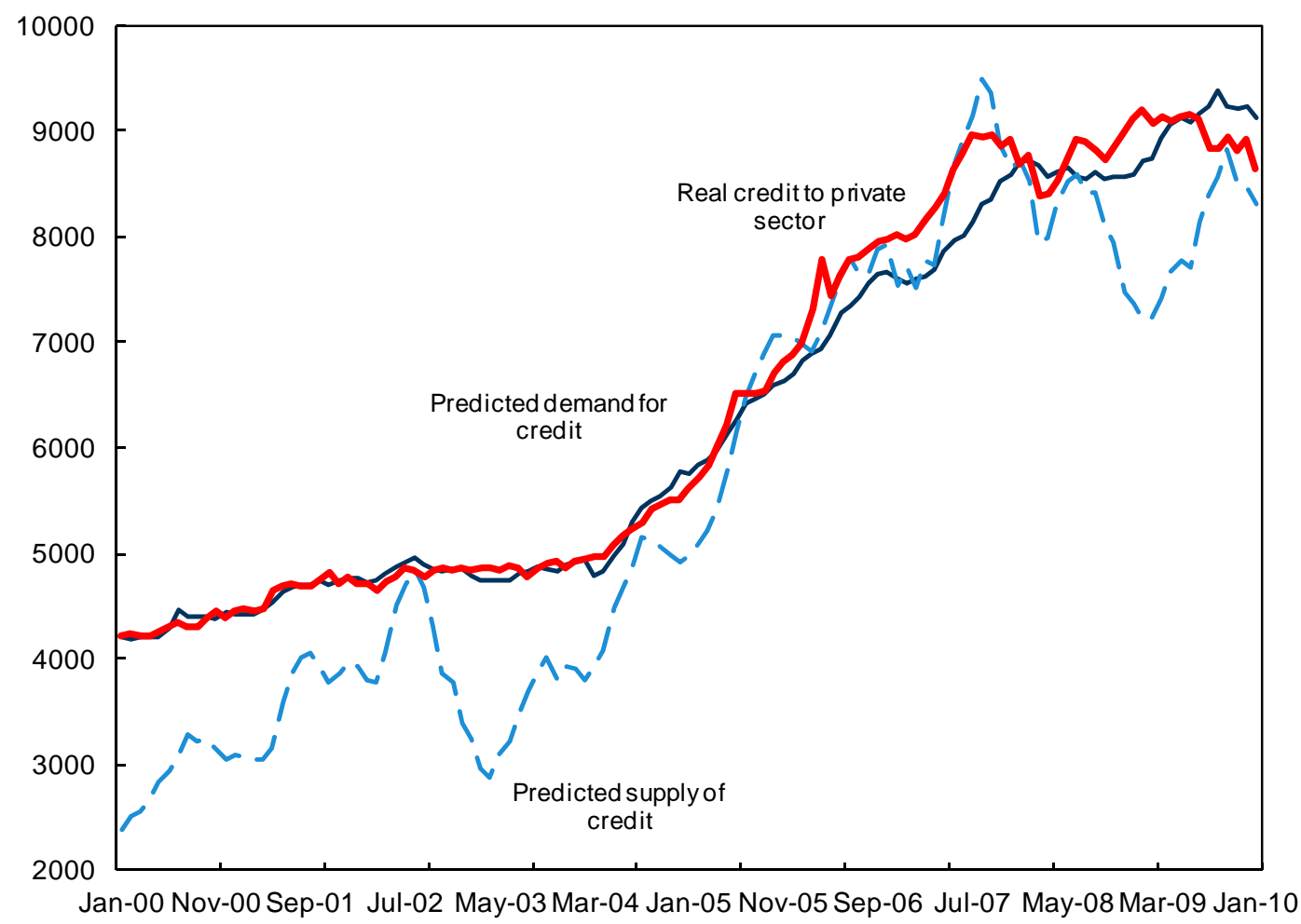

Figure 3. Jordan: Deviation of Demand and Supply from Observed Credit Volume

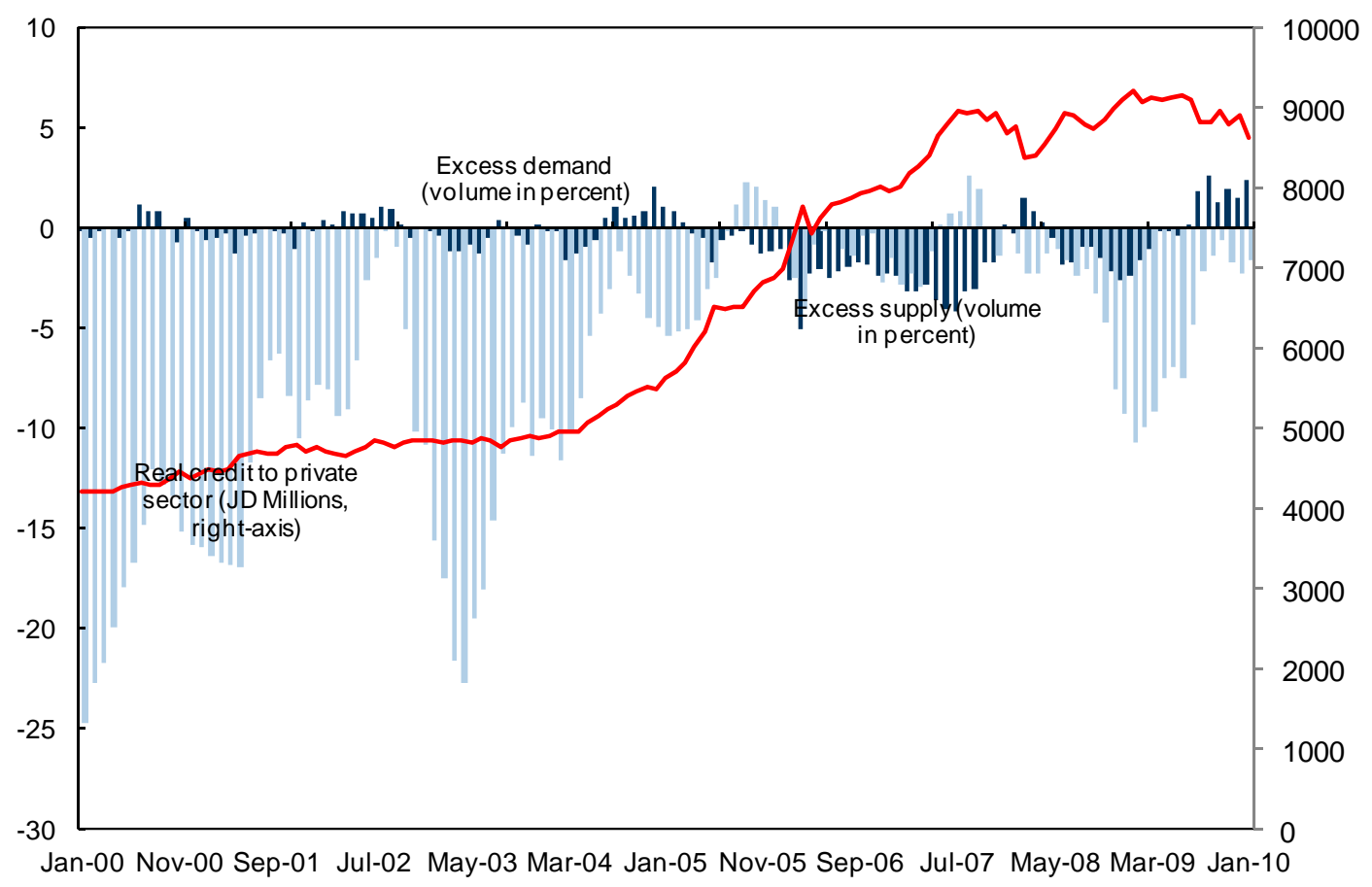




\section{Conclusion}

This paper estimates a disequilibrium model of credit supply and demand in Jordan. The main objective is to evaluate the relative role of demand and supply factors in the slowdown of credit flows in the Jordanian economy in the wake of the global financial crisis.

The estimation results support the credit crunch hypothesis, according to which the slowdown of credit activity in Jordan is a supply phenomenon owing to the tighter lending standards exercised by banks following the global financial crisis. Another factor that has contributed to restricted credit supply has been a widening of the interest differential between monetary policy rates in Jordan and the United States, which reflects the relatively tighter monetary policy exercised by the Jordanian monetary authorities in the wake of the global financial crisis. A higher policy rate in Jordan also increases bank returns from holding excess reserves at the $\mathrm{CBJ}$, and further discourages lending to the real sector.

In addition, we distinguish between banks' ability (lending capacity) and willingness (risk aversion) to lend and show that the former has a relatively stronger impact on the supply of bank credit. Estimations also suggest that the elasticity of credit demand with respect to the lending rate is also relatively smaller than the elasticity of credit supply. Taken together, these findings suggest that the equilibrium interest rate in Jordan is largely affected by shifts in credit supply.

In a nutshell, the results of this study suggest that economic policies targeted towards stimulating credit supply are likely to be a more effective tool for expanding credit flows in Jordan relative to demand-stimulating policies. In particular, the monetary easing which occurred between November 2008 and February 2010, by narrowing the gap between policy rates in Jordan and the United States, looks to have assisted in expanding the supply of bank credit. 


\section{APPENDIX}

The disequilibrium approach is based on the notion that the observed volume of loans $\left(C_{t}\right)$ is the minimum of demand $\left(C^{D}\right)$ and supply $\left(C^{S}\right)$, as indicated in equation (3). Let $\theta_{t}$ denote the probability that the observation $C_{t}$ belongs to the demand equation:

$\theta_{t}=\operatorname{Pr}\left(C^{D}{ }_{t}<C^{S}{ }_{t}\right)=\operatorname{Pr}\left(\beta^{\prime} X^{D}{ }_{t}+\varepsilon^{D}{ }_{t}<\alpha^{\prime} X^{S}{ }_{t}+\varepsilon^{S}{ }_{t}\right)=\operatorname{Pr}\left(\varepsilon^{D}{ }_{t}-\varepsilon^{S}{ }_{t}<\alpha^{\prime} X^{S}{ }_{t}-\beta^{\prime} X^{D}{ }_{t}\right)$

where $X^{S}$ and $X^{D}$ are vectors of credit supply and demand determinants, respectively, and $\alpha$ and $\beta$ are corresponding coefficients. Assuming that $\varepsilon^{D}$ and $\varepsilon^{S}$ are normally and independently distributed with variances $\sigma^{2 D}$ and $\sigma^{2 S}$, their difference $\varepsilon^{D}-\varepsilon^{S}$ is normally distributed with variance $\sigma^{2}=\sigma^{2 D}+\sigma^{2 S}$. Using this parameterization, equation (5) can be rewritten as:

$\theta_{t}=\int_{-\infty}^{\left(\alpha^{\prime} X^{S}{ }_{t}-\beta^{\prime} X^{D}{ }_{t}\right) / \sigma} \frac{1}{\sqrt{2 \pi}} e^{-\frac{\varepsilon^{2}}{2}} d \varepsilon$

Now let's define the probability density functions of credit supply $\left(f^{S}\right)$ and demand $\left(f^{D}\right)$ as:

$$
\begin{aligned}
f^{D}\left(C_{t}\right) & =\frac{1}{\sqrt{2 \pi \sigma^{D}}} e^{-\frac{1}{2 \sigma^{2 D}}\left(C_{t}-\beta^{\prime} X^{D}\right)^{2}} \\
f^{S}\left(C_{t}\right) & =\frac{1}{\sqrt{2 \pi \sigma^{S}}} e^{-\frac{1}{2 \sigma^{2 S}}\left(C_{t}-\alpha^{\prime} X^{S}\right)^{2}}
\end{aligned}
$$

The corresponding cumulative density functions for credit supply $\left(F^{S}\right)$ and demand $\left(F^{D}\right)$ are given by:

$$
\begin{aligned}
& F^{D}\left(C_{t}\right)=\frac{1}{\sqrt{2 \pi \sigma^{D}}} \int_{C_{t}}^{\infty} e^{-\frac{1}{2 \sigma^{2 D}}\left(C^{D}{ }^{-}-\beta^{\prime} X^{D}{ }_{t}\right)^{2}} d C_{t}^{D} \\
& F^{S}\left(C_{t}\right)=\frac{1}{\sqrt{2 \pi \sigma^{S}}} \int_{C_{t}}^{\infty} e^{-\frac{1}{2 \sigma^{2 S}\left(C^{S}{ }_{t}-\alpha^{\prime} X^{S}\right)^{2}}} d C_{t}^{S}
\end{aligned}
$$

Using this notation, the density function of credit conditional on excess supply (or conditional on credit laying on the demand curve) can be written as:

$$
f\left(C_{t} \mid C_{t}^{D}<C_{t}^{S}\right)=\frac{f^{D}\left(C_{t}\right) F^{S}\left(C_{t}\right)}{\theta_{t}}
$$

Similarly, the density function of credit conditional on excess demand (or conditional on credit laying on the supply curve) is: 
$f\left(C_{t} \mid C^{S}{ }_{t}<C^{D}{ }_{t}\right)=\frac{f^{S}\left(C_{t}\right) F^{D}\left(C_{t}\right)}{1-\theta_{t}}$

Since $C_{t}$ lies on the demand equation with probability $\theta_{t}$ and on the supply equation with probability $\left(1-\theta_{t}\right)$, the unconditional density of $C_{t}$ given the observed values of determinants of credit demand $\left(X^{D}\right)$ and supply $\left(X^{S}\right)$ can be written as follows:

$$
\begin{aligned}
f\left(C_{t} \mid X^{S}{ }_{t}, X^{D}{ }_{t}\right) & =\theta_{t} \frac{f^{D}\left(C_{t}\right) F^{S}\left(C_{t}\right)}{\theta_{t}}+\left(1-\theta_{t}\right) \frac{f^{S}\left(C_{t}\right) F^{D}\left(C_{t}\right)}{1-\theta_{t}}= \\
& =f^{D}\left(C_{t}\right) F^{S}\left(C_{t}\right)+f^{S}\left(C_{t}\right) F^{D}\left(C_{t}\right)
\end{aligned}
$$

Hence, the log-likelihood function takes the form of equation (4). 


\section{REFERENCES}

Agénor, P., J. Aizenman, and A. Hoffmaister (2000), “The Credit Crunch in East Asia: What Can Bank Excess Liquid Assets Tell Us?”, NBER Working Paper No. 7951.

Barajas, A. and R. Steiner (2002), “Credit Stagnation in Latin America”, IMF Working Paper $\mathrm{WP} / 02 / 53$.

Berndt, E., B. Hall, R. Hall, and J. Hausman (1974), "Estimation and Inference in Nonlinear Structural Models”, Annals of Social Measurement, 3: 653-65.

Ghosh, A. and S. Ghosh (1999), "East Asia in the Aftermath: Was There a Crunch?”, IMF Working Paper WP/99/38.

International Monetary Fund (2010), “Jordan: 2010 Article IV Consultation”, IMF Country Report No. 10/297, International Monetary Fund: Washington, DC.

Kim, H. (1999), "Was Credit Channel a Key Monetary Transmission Mechanism Following the Recent Financial Crisis in the Republic of Korea?”, World Bank Policy Research Working Paper No. 3003.

Laffont, J-J. and R. Garcia (1977), “Disequilibrium Econometrics for Business Loans”, Econometrica, 45(5): 1187-1204.

Maddala, G. and F. Nelson (1974), “Maximum Likelihood Methods for Models of Market Disequilibrium”, Econometrica, 42(6): 1013-30.

Pazarbasioglu, C. (1997), “A Credit Crunch? Finland in the Aftermath of the Banking Crisis”, IMF Staff Papers, 44(3): 315-27.

Poddar, T., R. Sab, and H. Khachatryan (2006), “The Monetary Transmission Mechanism in Jordan”, IMF Working Paper WP/06/48.

Stiglitz, J. and A. Weiss (1981), “Credit Rationing in Markets with Imperfect Information”, American Economic Review, 71: 393-410. 